\title{
EXPERIMENTAL STUDY AND NUMERICAL BEHAVIOR OF SOLID WOOD AND GLUED WOOD IN REQUESTED MODE I: MOROCCAN WOOD CASE OF GROWN EUCALYPTI AND QUERCUS ILEX
}

\author{
Abdelmajid Daya ${ }^{1}$, Abdelhadi Elhakimi ${ }^{2}$, Zitouni Azari ${ }^{3}$ \\ ${ }^{1}$ Laboratoire de Modélisation en Mécanique-Energétique et Systèmes Automatiques (LMMESA), Département de \\ Physique, Faculté des Sciences et Techniques d'Errachidia, Université My Ismaïl, BP 509 Boutalamine, 52000 \\ Errachidia, Maroc \\ ${ }^{2}$ Département de Génie Mécanique, Faculté des Sciences et Techniques de Fès, Université Sidi Mohamed Ben \\ Abdellah, BP 2202, Route Imouzzer, Fès, Maroc \\ ${ }^{3}$ Laboratoire de Mécanique Biomécanique Polymère Structure (LaBPS), Ecole Nationale d'Ingénieur de Metz, \\ Université Paul Verlaine Metz, 1 route d'Ars Laquenexy, 57078 Metz, France
}

\begin{abstract}
Fracture toughness $G_{I c}$ of solid wood and glued wood species of Grown Eucalypti and Quercus ilex was given via the compliance method of DCB specimen. The numerical values of fracture toughness determined by finite elements Castem 2000 and the analytical methods are compared with the experimental results. We finally propose an analysis with the stereomicroscope of the features and fracture surfaces.
\end{abstract}

Keywords: Grown Eucalypti, Quercus ilex, solid wood, glued wood, fracture toughness, fracture topography

\section{INTRODUCTION}

The wood of Grown Eucalypti and Quercus ilex has many defects, from a physical and mechanical point of view [1], which reduce his field of application in industry. The possibilities of transformation of the solid wood of these two species are particularly limited by the release of the growth stress during demolition, slicing, by the development of slits and the problems which occur during drying [2]. Many research showed it, in particular the study of the indicators of constraint of growth GSI [3] and technological characteristics of grown Eucalypti and Quercus ilex [4].

Work on the tenacity of the couples wood - adhesive $[5,6]$ showed that this one depends on the relationship between the elastic properties of the wood turpentine, and those of the pure adhesive. Duchanois [5] measured this quantity for several couples wood-adhesive. He notes that the tenacity of certain essences is weakened by the presence of the joint of adhesive (beech) and others reinforced by adhesive (fir tree). This article presents a contribution to the valorization of these two unstable wood species in order to bring technical elements in the joints adhesive and to lead to a better knowledge of the quality of sawn timber and glued wood. The essential goal is to improve and optimize its uses.

\section{MATERIALS AND METHOD}

\subsection{Plant Material}

The plant material used includes three 45 years old trees of Eucalypti grown coming from Sidi Yahia Gharb $30 \mathrm{kms}$ from the town of Kénitra, and three 85 years old trees of the
Quercus ilex coming from Ain Kharzouza Azrou. The choice of the trees has been made in a simple and random way. The selected trees are of good strength, homogeneous and do not present any major defect.

A series of 5 test-tubes DCB (Fig.1) by species and tree without defects was made at the laboratory of the Physical Tests and Mechanics of wood in Rabat starting from the boards which have a moisture of $12,5 \%$. All the bonding is performed with adhesive polyurethane provided by company SEDEC in Temara.

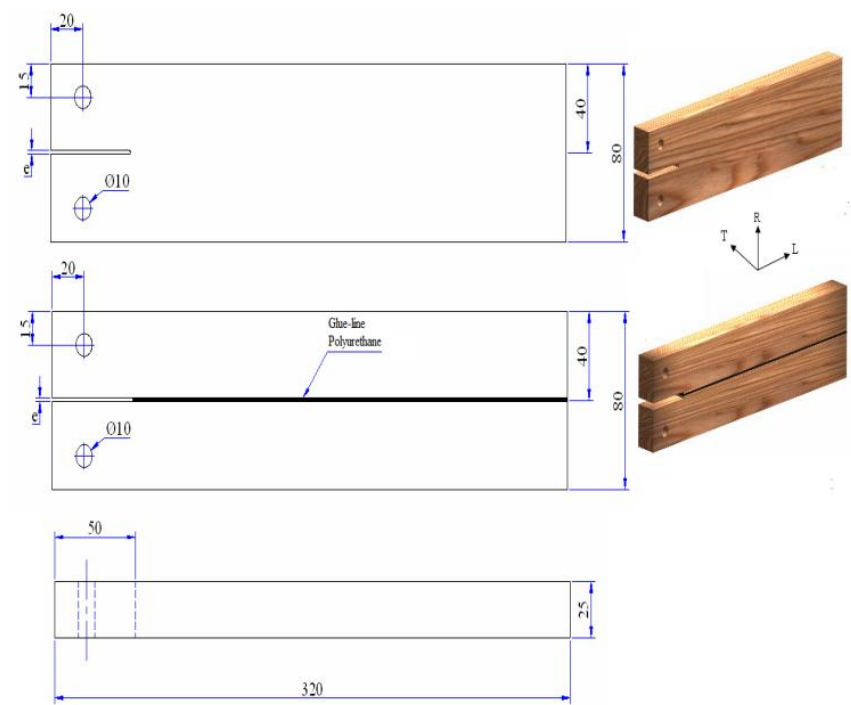

Fig-1: Geometrical characteristics of the DCB specimens. 


\subsection{Principle of the Testing}

The tests were carried out on a tensile testing machine TIRA TEST $28300 \mathrm{E} 12$ with a capacity of $300 \mathrm{kN}$, controlled by a computer which records the curve load-displacement (Fig.2). The rate of travel of the cross-piece was fixed at $1 \mathrm{~mm} / \mathrm{mn}$ for the DCB specimens (solid wood and glued wood).

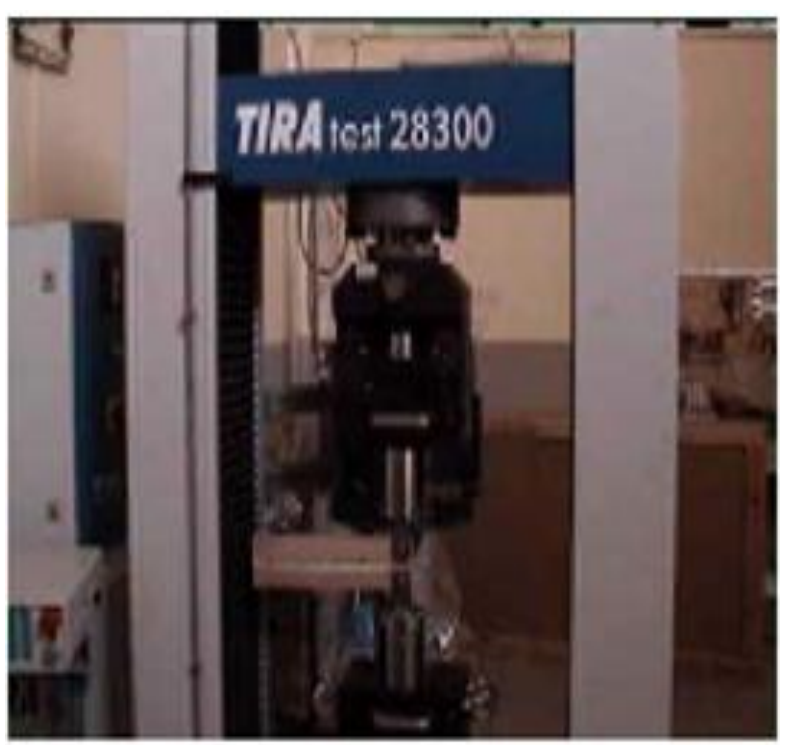

Fig-2: Principle of testing DCB specimens

\subsection{Observation of the Fracture Topography of}

\section{Solid Wood and Glued Wood}

The observations of the fracture topographies were carried out using a stereomicroscope with an enlargement X 2.5 (Fig.3). This apparatus is an optical microscope designed for the visual examination, on the basis of more recent scientific and technical training intended for the photomicrography and videoscopy of microscopic objects. It presents an interfacing controlled by a software of ZEISS treatment. The face of the test-tube is subjected under the apparatus or a halogen lamp is lit, a series of acquisition of photo are caught on the computer

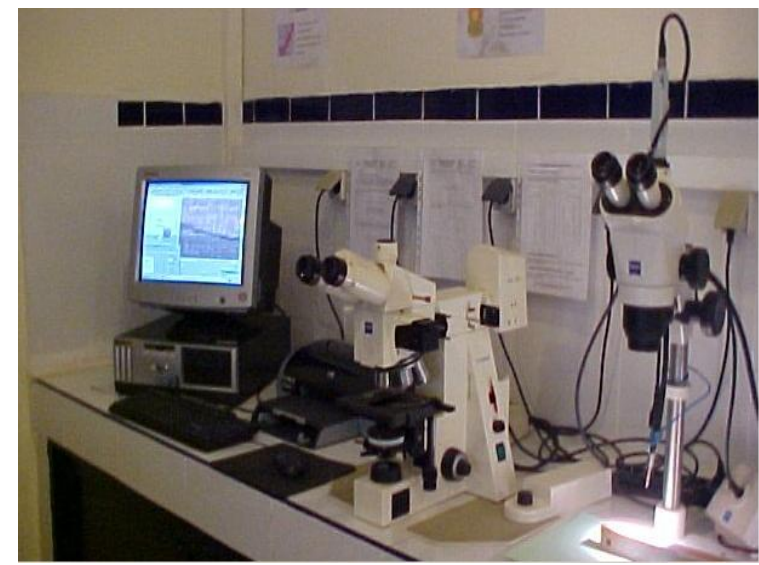

Fig- 3: Observation of the fracture topography using a stereomicroscope.

\section{RESULTS}

\subsection{Results of the Tests of Opening on Specimens} DCB in Mode I

\subsubsection{Curve Charges - Displacement}

Fig.4 shows the general shape of the curve loaddisplacement obtained for specimens DCB out of solid wood and glued wood species of Grown Eucalypti and Quercus ilex.
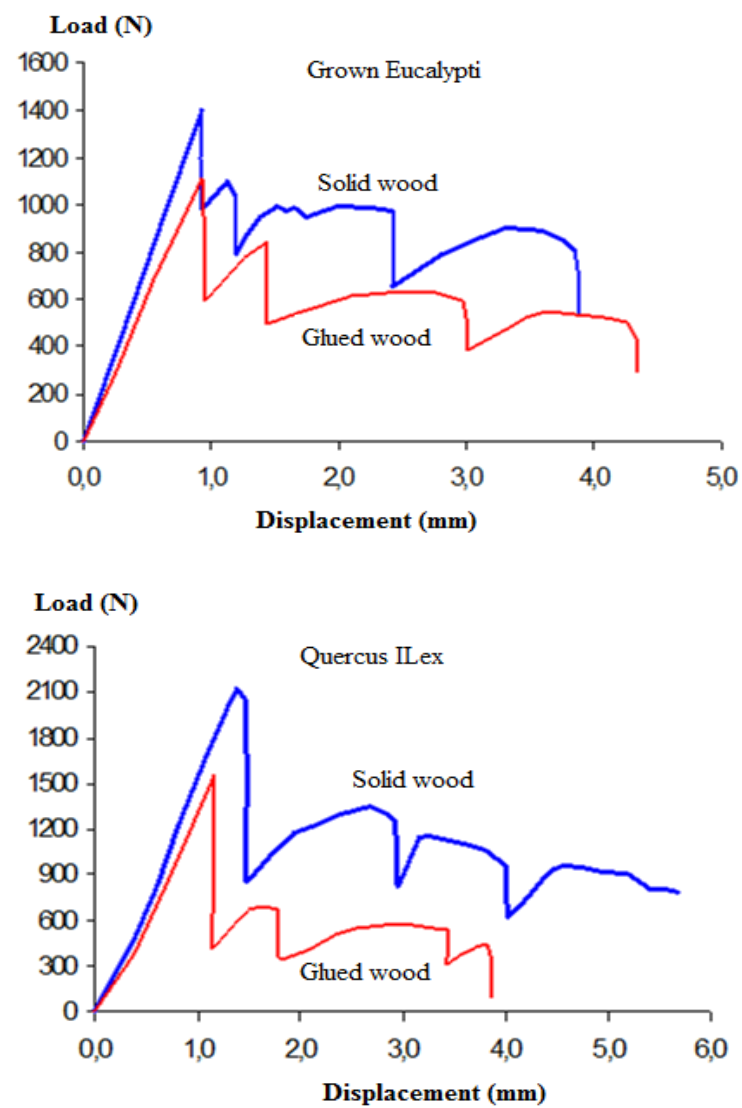

Fig- 4: Curve charges displacement for specimens DCB solid wood and glued wood

The applied load increases gradually causing the propagation of the crack until the final crack of the specimens. The characteristics load-displacement presents elastic and non elastic ranges. We notice the absence of propagation of the crack before the peak of the load, and that the nonlinear behavior before the other peaks is due to a development of microscopic cracks. Reduction in rigidity, generated after each peak, is due to an increase of the length of the crack.

\subsubsection{Curve of Compliance}

For each specimen DCB, we traced compliance according to the length of crack a. compliance $\mathrm{C}$ represents the slope of the curve load-displacement in its linear part: 


$$
C=\frac{\delta}{P}
$$

Where $\mathrm{P}$ is the load and $\delta$ the opening of the crack

Fig.5 illustrates the evolution of compliance $\mathrm{C}$ according to the length of the crack, for solid wood and glued species of Grown Eucalypti and Quercus ilex.
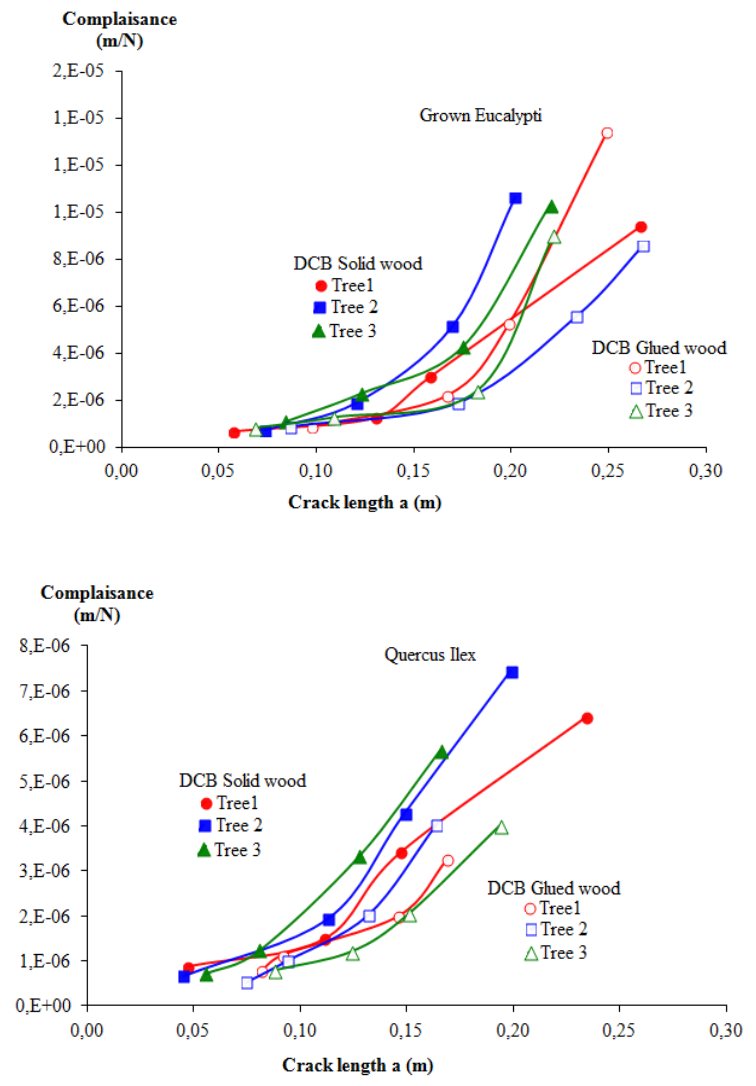

Fig-5: Curve of compliance of specimens DCB solid wood and glued wood

Measured compliance, on glued wood, is similar to that measured for solid wood. We notice that the rigidity of the two essences decreases according to the length of the defect. The joint of polyurethane adhesive thus does not have any notable influence on the rigidity of the specimens.

\subsubsection{Fracture Toughness of Solid Wood and Glued}

\section{Wood}

Fracture toughness $G_{1 c}$, in term of energy release rate of refund of energy represents energy necessary to create two surfaces of value bda, where B is the thickness and da the unit increment length of crack, is given by:

$$
G_{1 C}=\frac{P^{2}}{2 b} \frac{\partial C}{\partial a}
$$

For the approximation of the curve of compliance according to the length of the crack, we chose a smoothing of the experimental points by using an exponential function, makes it possible to obtain the value of $\mathrm{dC} / \mathrm{da}$.

Fig. 6 shows that the fracture toughness of the solid wood of the two species is much higher than that of glued wood, and that the solid wood of Quercus ilex is tougher than the Grown Eucalyptus. This could be explained by the anatomical differences in these two leafy species, the age and the particular structure (tension wood), used adhesive and also by random ruptures in the adhesive or wood.
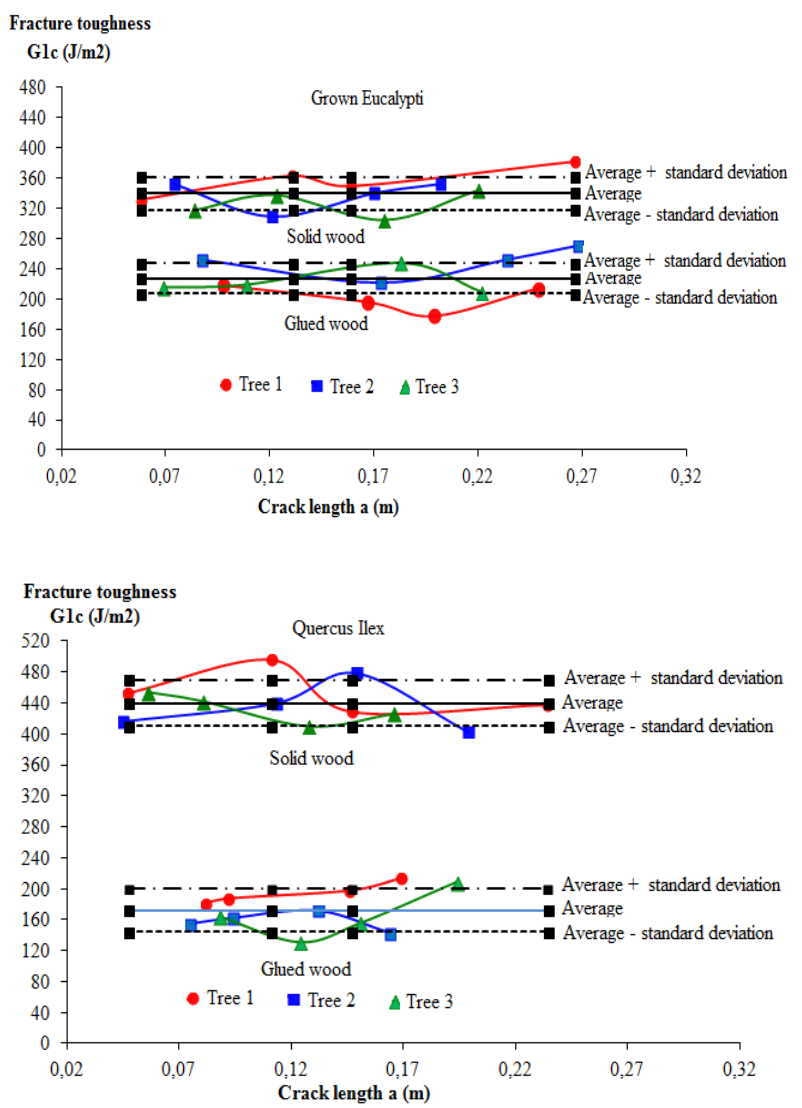

Fig- 6: Fracture toughness according to the length of the crack of solid wood and glued wood

The experimental results show that the values of $\mathrm{G}_{1 \mathrm{c}}$ tenacity of sawn timber and glued wood of Grown Eucalypti and Quercus ilex species are independent from the length of the crack and it proves that fracture toughness $G_{1 c}$ is a characteristic for good of studied materials

\subsection{Confrontation of Our Experimental Results with Other Methods.}

Fracture toughness can be given in several ways. In our study, we chose three other methods to compare them with the experimental compliance method

Method relating to standard ASTM D 3433-75

$$
G_{1 C}^{A S T M}=\frac{4 P_{C}^{2}}{E_{L} b^{2}}\left[\frac{3 a^{2}}{h^{3}}+\frac{1}{h}\right]
$$


Specimen DCB considered as two fixed beams

$$
G_{1 C}^{A S T M}=\frac{4 P_{C}^{2}}{E_{L} b^{2}}\left[\frac{3 a^{2}}{h^{3}}+0.3 \frac{E_{L}}{G_{L T} h}\right]
$$

With $\mathrm{P}_{\mathrm{C}}$ : Critical load applied to the system a: Initial length of the crack b: Thickness of the test-tube

$\mathrm{E}_{\mathrm{L}}$ : longitudinal modulus of elasticity of inflection

$\mathrm{G}_{\mathrm{LT}}$ : Modulus of rigidity corresponding to plan LT

Calculations by finite elements (Castem 2000

The behaviour of solid wood and glued wood is orthotropic and the isotropic adhesive.

Table-1: Rheological constants of the wood of grown Eucalypti and Quercus ilex (E and G in MPa) [1]

\begin{tabular}{|l|l|l|}
\hline $\begin{array}{l}\text { Rheological } \\
\text { constants }\end{array}$ & Grown Eucalypti & Quercus ilex \\
\hline $\mathrm{E}_{\mathrm{R}}$ & 1680 & 2023 \\
\hline $\mathrm{E}_{\mathrm{T}}$ & 879 & 1296 \\
\hline $\mathrm{E}_{\mathrm{L}}$ & 14300 & 15100 \\
\hline$v_{\mathrm{RT}}$ & 0,67 & 0,65 \\
\hline$v_{\mathrm{TR}}$ & 0,36 & 0,42 \\
\hline$v_{\mathrm{LT}}$ & 0,47 & 0,45 \\
\hline$v_{\mathrm{TL}}$ & 0,03 & 0,04 \\
\hline$v_{\mathrm{RL}}$ & 0,04 & 0,05 \\
\hline$v_{\mathrm{LR}}$ & 0,38 & 0,40 \\
\hline $\mathrm{G}_{\mathrm{TL}}$ & 914 & 1080 \\
\hline $\mathrm{G}_{\mathrm{RL}}$ & 1215 & 1359 \\
\hline $\mathrm{G}_{\mathrm{RT}}$ & 312 & 460 \\
\hline
\end{tabular}

où: $\mathrm{E}_{\mathrm{R}}, \mathrm{E}_{\mathrm{T}}, \mathrm{E}_{\mathrm{L}}$ : Young moduli in the three directions $\mathrm{R}, \mathrm{T}, \mathrm{L}$, $\mathrm{G}_{\mathrm{TL}}, \mathrm{G}_{\mathrm{RL}}, \mathrm{G}_{\mathrm{RT}}$ : Moduli of rigidity and $v_{\mathrm{TR}}, v_{\mathrm{RL}}, v_{\mathrm{TL}}$ : Poisson's ratios

Table-2: Characteristics of the adhesive polyurethane [7]

\begin{tabular}{|l|l|l|l|l|}
\hline \multirow{2}{*}{$\begin{array}{l}\text { Polyurethane } \\
\text { adhesive }\end{array}$} & $\begin{array}{l}\mathrm{E} \\
(\mathrm{MPa})\end{array}$ & $v$ & $\begin{array}{l}\mathrm{G} \\
(\mathrm{MPa})\end{array}$ & $\begin{array}{l}\mathrm{G}_{1 \mathrm{c}} \\
\left(\mathrm{J} / \mathrm{m}^{2}\right)\end{array}$ \\
\cline { 2 - 5 } & 2133 & 0,35 & 790 & 150 \\
\hline
\end{tabular}

In order to compare our analytical and experimental results of $G_{1 c}$, we modelled with two dimensions specimens DCB.

\subsection{Modeling}

At the beginning, we defined

- The geometry solid wood of specimens DCB and glued wood

- The type of elements: triangular elements with 6 nodes (TRI6);

- The behavior: wood orthotropic linear elastic material and the isotropic adhesive elastic material.

- Boundary condition: specimen DCB is blocked according to $\mathrm{Y}$, and the loading is applied in the holes.
The result of the mesh, loading and deformation are presented in Fig.7a and Fig.7b. Procedure G-THETA allows us to calculate fracture toughness

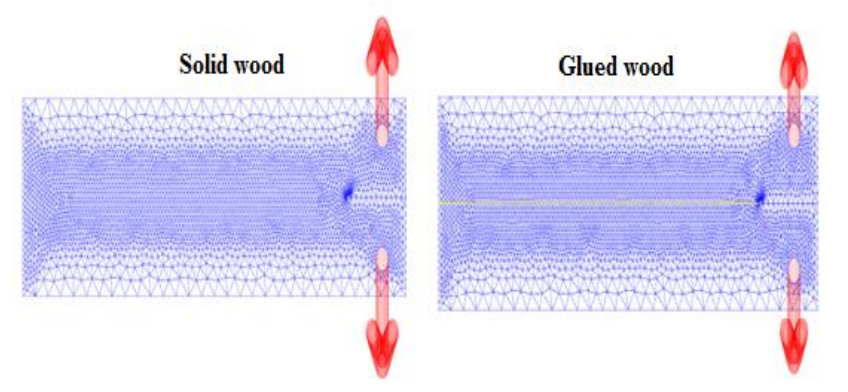

Fig- 7a: Mesh and loading of specimens DCB

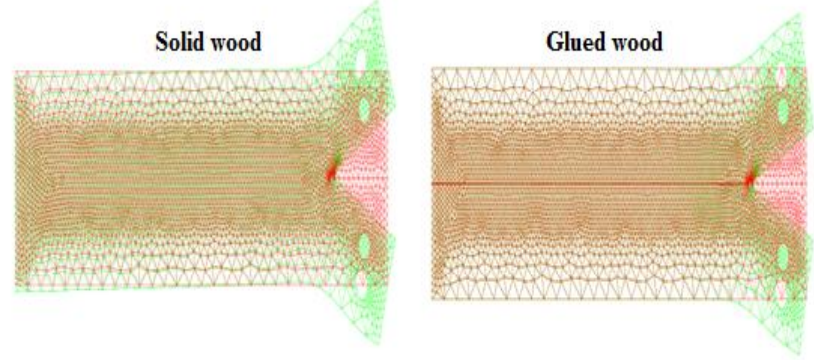

Fig- 7b: Deformation of specimens DCB

Tables 3 and 4 gather the values of the average fracture toughness of the three trees of each species with their coefficient of variation, and of each tree of Grown Eucalypti and Quercus ilex out of solid wood and glued wood, compared with that determined by finite elements and the analytical methods.

Table- 3: Comparisons of experimental fracture toughness, analytical and numerical. Average of the three trees and each tree of solid wood and the glued wood of Grown Eucalypti

\begin{tabular}{|l|l|l|l|}
\hline \multirow{4}{*}{$\mathrm{G}_{1 \mathrm{c}}\left(\mathrm{J} / \mathrm{m}^{2}\right)$} & $\mathrm{N}^{\circ}$ of tree & $\begin{array}{l}\text { Solid } \\
\text { wood } \\
(\mathrm{CV} \%)\end{array}$ & $\begin{array}{l}\text { Glued wood } \\
(\mathrm{CV} \%)\end{array}$ \\
\hline \multirow{4}{*}{ Experimental } & 1 & $357(6)$ & $198(11)$ \\
\cline { 2 - 4 } & 2 & $339(6)$ & $253(9)$ \\
\cline { 2 - 4 } & 3 & $326(6)$ & $232(8)$ \\
\cline { 2 - 4 } & Average & $\mathbf{3 4 1}$ & $\mathbf{2 2 7}$ \\
\hline \multirow{3}{*}{$\begin{array}{l}\text { Two fixed } \\
\text { beams }\end{array}$} & 1 & $337(15)$ & $232(17)$ \\
\cline { 2 - 4 } & 2 & $292(28)$ & $206(32)$ \\
\cline { 2 - 4 } & 3 & $314(26)$ & $224(18)$ \\
\cline { 2 - 4 } & Average & $\mathbf{3 1 4}$ & $\mathbf{2 2 1}$ \\
\hline \multirow{3}{*}{$\begin{array}{l}\text { ASTM } \\
\text { D3433-75 }\end{array}$} & 1 & $306(19)$ & $210(15)$ \\
\cline { 2 - 4 } & 2 & $247(23)$ & $182(38)$ \\
\cline { 2 - 4 } & 3 & $274(32)$ & $196(24)$ \\
\hline Castem2000 & Average & $\mathbf{2 7 6}$ & $\mathbf{1 9 6}$ \\
\hline
\end{tabular}


Table- 4: Comparisons of experimental fracture toughness, analytical and numerical. Average of the three trees and each tree of solid wood and the glued wood of Quercus ilex

\begin{tabular}{|l|l|l|l|}
\hline \multirow{3}{*}{$\mathrm{G}_{1 \mathrm{c}}\left(\mathrm{J} / \mathrm{m}^{2}\right)$} & $\mathrm{N}^{\circ}$ of tree & $\begin{array}{l}\text { Solid wood } \\
(\mathrm{CV} \%)\end{array}$ & $\begin{array}{l}\text { Glued wood } \\
(\mathrm{CV} \%)\end{array}$ \\
\hline \multirow{4}{*}{ Experimental } & 1 & $454(7)$ & $195(7)$ \\
\cline { 2 - 4 } & 2 & $434(8)$ & $158(8)$ \\
\cline { 2 - 4 } & 3 & $433(4)$ & $164(8)$ \\
\cline { 2 - 4 } & Average & $\mathbf{4 3 3}$ & $\mathbf{1 7 2}$ \\
\hline \multirow{3}{*}{$\begin{array}{l}\text { Two fixed } \\
\text { beams }\end{array}$} & 1 & $472(40)$ & $194(26)$ \\
\cline { 2 - 4 } & 2 & $399(31)$ & $147(16)$ \\
\cline { 2 - 4 } & 3 & $412(36)$ & $164(26)$ \\
\hline \multirow{3}{*}{$\begin{array}{l}\text { ASTM } \\
\text { D3433-75 }\end{array}$} & 1 & $\mathbf{4 2 8}$ & $\mathbf{1 6 8}$ \\
\cline { 2 - 4 } & 2 & $403(42)$ & $168(31)$ \\
\cline { 2 - 4 } & 3 & $344(36)$ & $128(15)$ \\
\cline { 2 - 4 } & Average & $\mathbf{3 6 6}$ & $\mathbf{1 4 5}$ \\
\hline Castem2000 & Average & $\mathbf{4 3 5}$ & $\mathbf{1 7 0}$ \\
\hline
\end{tabular}

We notice that experimental results that we have realized, are in concordance with those determined by the use of the code finite elements, however a significant difference with those obtained by the method of two fixed beams and by the method of ASTM D3433-75.

\subsection{Results of Observation of the Fracture}

\section{Topography}

\subsubsection{Crack Initiation of a Solid Wood}

In solid wood, the crack starts in the plan having less resistance. On the level of the bottom of notch, the crack starts on several levels.
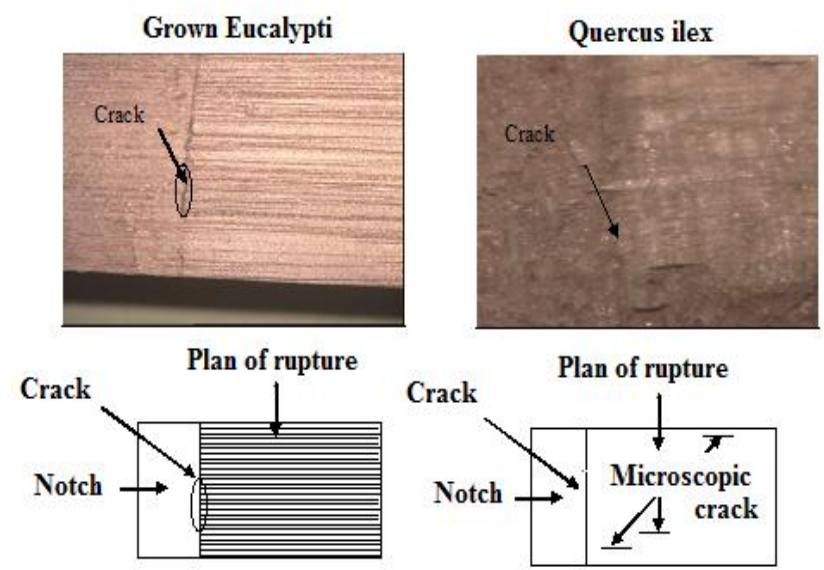

Fig- 8: Crack initiation of a solid wood of the specimens DCB (enlargement X 2.5)

We distinguish one plan from rupture for the two species. A bottom of crack is less easy to observe for the Quercus ilex. The microscopic cracks are on the edges. Uniformity, the homogeneity and the longitudinal continuity of the elements on the rough surface indicate resistance met during the crack initiation

\subsubsection{Crack Initiation of Glued Wood.}

Two kinds of crack initiation are noticed for wood of grown eucalypti. The first is noticed in wood and the other in the joint of adhesive. The bottom of crack is disturbed by the presence of the adhesive. For the wood of Quercus ilex, starting is only observed on the joint of adhesive. We note that the penetration of the adhesive is more important for the wood of Grown Eucalypti

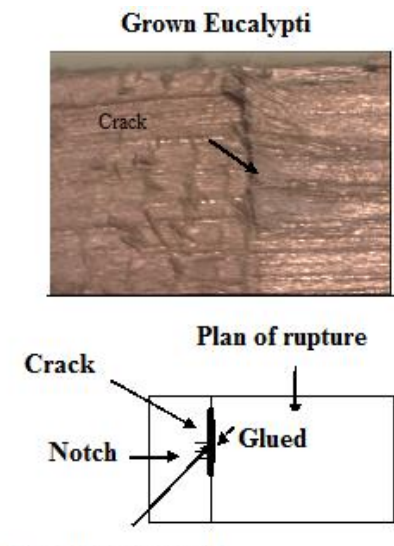

Wrenching in wood and the adhesive

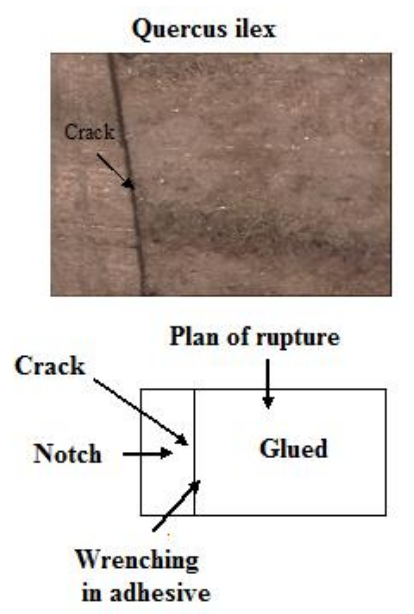

in adhesive

Fig- 9: Crack initiation of glued wood of the specimens DCB (enlargement X 2.5)

\subsubsection{Propagation of the Crack of Solid Wood}

At certain places of the rough surface, we do not visualize the band of woody ray but only their trace on the wood of the sub-base. The missing part is on the other face of the broken sample (Fig. 10). This shows two things:

1- First that the wall of the bands of woody rays remained intact, there is thus a rupture of an intercellular type.

2- Second, there was a transverse cutting of the cells and thus a rupture of the transcellular type. This rupture is accompanied by a local decoherence of the cells.


Fig-10: Propagation of the crack of solid wood the specimens DCB (enlargement X 2.5) 


\subsubsection{Propagation of the Crack of Glued Wood}

On sample DCB of the wood of Quercus ilex, the propagation of the crack always takes place in the joint of adhesive. The rupture is of the cohesive type. On the wood of Grown Eucalypti, the propagation of the crack is in both wood and adhesive.
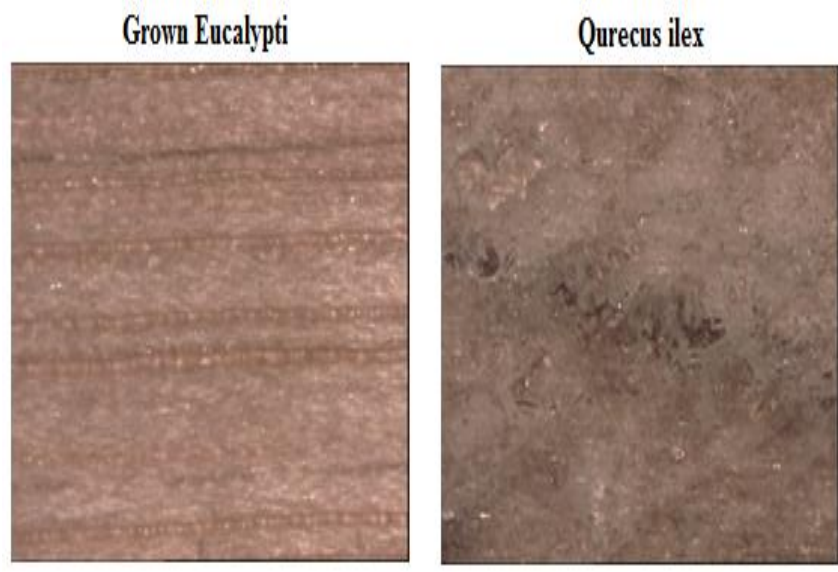

Fig-11: Propagation of the crack of glued wood the specimens DCB (enlargement X 2.5)

\section{CONCLUSIONS}

Within the framework of the valorization of national wood, in particular nervous wood of Grown Eucalypti and Quercus ilex, we compared the failure stress and the fracture toughness of solid wood and glued wood.

The fracture toughness of the solid wood and glued wood of Grown Eucalypti $\left(\mathrm{G}_{1 \mathrm{c} \text { solid }}=341 \mathrm{~J} / \mathrm{m}^{2}\right.$ and $\mathrm{G}_{1 \mathrm{c} \text { glued }}=227$ $\left.\mathrm{J} / \mathrm{m}^{2}\right)$ and Quercus ilex $\left(\mathrm{G}_{1 \mathrm{c} \mathrm{solid}}=433 \mathrm{~J} / \mathrm{m}^{2}\right.$ and $\mathrm{G}_{1 \mathrm{c} \mathrm{glued}}=172$ $\mathrm{J} / \mathrm{m}^{2}$ ) is realized by the compliance method.

The fracture toughness measured by the experimental method, is very close to that deduced by calculation with the finite elements, slightly higher than that calculated by other methods of two fixed beams and by the method of ASTM D3433-75.

The analysis of the fracture topographies by the stereomicroscope revealed, that in solid wood, the crack starts in the plan having less resistance whereas in glued wood, it starts in the joint of adhesive for the Quercus ilex, and at the same time in the adhesive and wood for the Grown Eucalyptus. During the propagation of the crack, the types of rupture observed in solid wood are intercellular and transcellular, whereas in glued wood, they are always adhesive for the Quercus ilex and alternatively in wood and the adhesive for the Grown Eucalypti.

The adhesive bonded joint can be a solution for these two nervous leafy trees considered difficult. These two essences considerably occupy an interest of establishment in Morocco and enter a policy of valorization (average rigidity) to minimize the importation of the wood from the outside such as the silver fir usually used in industry of glued - laminated.

\section{REFERENCES}

[1]. Daya A., Chergui M, Famiri A., Jodin P., Azari Z., Elghorba,. Etude comparative de quelques propriétés physiques et mécaniques des bois d'eucalyptus grandis et de chêne vert. 7ème Congrès de Mécanique, Casablanca, Maroc. 19-22 avril 2005.

[2]. Jullien, D., Famiri, A., Gril, J., Laghdir, A., Observation of log-end cracks caused by growth stress in Eucalyptus, pp. 483-486, 3rd Plant Biomechanics Conference, Badenweiler (Freiburg), Germany,27.8-2.9.00, Thieme-Verlag (pub.), 2000

[3]. Daya. A., Azari Z., Study of growth stress and resistance of the cracking of the wood of Grown Eucalypti and Quercus Ilex. International Journal of Engineering Research \& Technology (IJERT), Vol. 3 Issue 5, pp, 117121, May - 2014

[4]. Daya. A., Famiri A., Azari Z., Contribution to the valorization of moroccan wood in industry of laminated wood: case of Grown Eucalypti and Quercus ilex. International Journal of Research in Engineering and Technology (IJERT), Vol. 3 Issue 5, pp, 398-402, May 2014

[5]. Duchanois G., Measure of tenacity and study of the mechanical behaviour of joints wood - glue. Thése, INPL. 1984

[6]. Haller P., Jodin P., Pluvinage G., Numerical simulation of assemblage glued together wooden by finished elements. Industrial Applications. Magazine of Optimization of Structures and Computer-Aided Design, pp, 121-138. 1987 [7]. JERONE M G., An improved method for fracture cleavage testing of adhesively-bonded wood Masters of Sciences, Blacksburg, Virginia, 2001 